\title{
Cartografar musicalidades: rastrear encontros ${ }^{21}$
}

\section{Cartography musicalities: tracking encounters}

\section{Vyullheney Lacava 22 \\ Norma Takeuti ${ }^{23}$}

\section{Resumo}

Este artigo reflete a partir de uma experimentação cartográfica os encontros realizados no seio das festas e musicalidades. Problematizamos a criação de espaços de atuação onde são percebidas liberdades momentâneas, onde o corpo embriaga-se de músicas e se desloca das sobrecodificações cotidianas da vida na cidade. Remixamos músicas para compor uma escrita cartográfica afetada pelas musicalidades, maneira de apresentar os encontros que se realizam com músicas.

Palavras-chave: cartografia. Musicalidades. Encontros. Festas.

\begin{abstract}
This article reflects from a cartographic experimentation the meetings held within the parties and musicality. We questioned the creation of work spaces where momentary freedoms are realized, where the body drunk to music and moves of everyday overcodings of city's life. Remixed songs to compose a written cartographic affected by musicality, way of presenting the encounters that take place with music.
\end{abstract}

Keywords: cartography. Musicality. Meetings. Parties.

\footnotetext{
${ }^{21}$ O presente texto é baseado em uma parte integrante do primeiro capítulo da dissertação de mestrado intitulada de Cartografia do Close: platôs festivos, platôs musicais, defendida por Vyullheney Fernandes de Araújo Lacava, orientada por Norma Missae Takeuti e apresentada ao Programa de Pós Graduação em Ciências Sociais da Universidade Federal do Rio Grande do Norte, em 29 de janeiro de 2016.

22 Programa de Pós-Graduação em Ciências Sociais pela Universidade Federal do Rio Grande do Norte (Doutorando); ORCID: https://orcid.org/0000-0002-5194-8948. Email: vyullheney@yahoo.com.br; Integrante do Grupo de Estudos Culturas e Subjetividades - Poiesis/UFRN e Egresso do Núcleo Interdisciplinar de Estudos em Diversidade Sexual, Gênero e Direitos Humanos - Tirésias/UFRN.

23 Professora titular do departamento de Ciências Sociais da Universidade Federal do Rio Grande do Norte. Coordenadora do Grupo de Estudos - Culturas e Subjetividades-Poiesis/UFRN. Email: normitk@gmail.com.
} 
Hibrida é a nossa concepção com respeito a nós mesmos, porque em nós fazemos experiências que não nos atreveriamos a fazer em animal algum, e seccionamos a nossa alma com satisfação e curiosidade. (Friedrich Nietzsche, Genealogia da moral)

Pensar é experimentar, não interpretar, mas experimentar, e a experimentação são sempre o atual, o nascente, o novo, o que está em vias de se fazer. (Gilles Deleuze - Conversações)

\section{Introdução}

O presente artigo se propõe a uma reflexão acerca da composição cartográfica no seio dos encontros com musicalidades, refletindo o contexto da produção de uma pesquisa que vislumbra eventos festivos que ocorreram em Natal-RN. O traçado cartográfico inspiração em Deleuze e Guattari (2011; 2012a; 2012b) e Rolnik (2011), intentando apresentar a trajetória de encontros que se realizam no seio da pesquisa, como forma de ligação com aquilo que Deleuze (1992, p.109, grifo nosso) demarcou que buscava pesquisar "a formação do novo, a emergência ou o que Foucault chama de atualidade". Utilizando em toda sua escritura a inserção de trechos musicais que coadunam com as noções dos escritos dos intercessores intelectuais aqui elencados.

Artes, festas, corpos. Curiosidades, conexões. Desinteresses nas grandes coisas, saborear miudezas. Saborear, deglutir. Conhecendo e comendo o mundo. Arrepios na nuca, um corpo ofegante. Ambiência, arredores, zonas de contato. Algo está acontecendo, meu corpo não obedece minha mente e razão. Eu quero sempre mais! Eu espero sempre mais de til. Canta Pitty e a banda Ira na canção Eu quero sempre mais ${ }^{24}$. Não quero só você, quero você e tudo aquilo que diz respeito ao teu universo, fazendo os meus mundos conversarem com os seus. Quem deseja não sou eu, é o meu mundo que vem a reboque de tudo o que já vivi e encontrei pela vida. Desço um degrau e vou mais longe, não me vejo: vejo

${ }^{24}$ Eu quero sempre mais, interpretada por Pitty e Ira!. Disponivel em: https://youtu.be/iydqURMhUGk. Acesso: $15 / 01 / 2016$. 
extensões, prolongamentos, continuidades. Quando transo, não o faço sozinho: transamos. As nossas trocas são de fluxos que ultrapassam os nossos fluidos. Quero essa mulher solamente pra mim, mas muito mais, como canta Caetano Veloso 25 . Transar pessoas, transar noites, músicas, gozar encontros, afetos, possibilidades.

Gosto do jeito que você se despe dos costumes, o jeito que assume que o negócio é se arriscar, canta Pitty em Pequena morte ${ }^{26}$, tirando as roupas que compõem as predileções musicais, estéticas, espacialidades frequentadas. De repente a gente nessa dança muito doida. Rolando, suando, nunca para de pulsar, novamente cito a música da cantora para mostrar como dançamos de formas doidas na pista de dança, e o corpo já não para de latejar. Minha pequena morte, configurando um pequeno mundo que já se desloca e faz com que algo novo aconteça. Meu território, meu mapa, minha confusão e composição flutuante de linhas. Linhas da vida ${ }^{27}$ e da arte. Já não me encontro como antes, fugi. E na fuga descobri um novo lugar que é distante de casa, mas mesmo assim não deixa de carregar algo que remete a isso, talvez um casulo.

Haveria "fluxos de desejo" presentes nas produções artísticas? Cria-se uma música, um evento, uma playlist. Misturam-se palavras, ritmos e corpos. Mas, há algo da ordem da desordem, do disforme, de diferente. Algo que não existia surge, desde já eis a criação. Não existia e no espaço onde não havia, passa a haver. Dessa novidade passamos a ter contato com algo que veio. O quê? Eventos, festas, músicas, embriaguez.

Aqui, a opção pela cartografia do circuito de festas e produções musicais dá-se em razão da tentativa, assim como inspira Rolnik (2011, passim), de "apreender a alteridade em sua condição de campo de forças vivas que nos afetam e se fazem presentes em nosso corpo sob a forma de sensação" (p. 12), construindo então "o traçado de cartografias nos movimentos de criação da

\footnotetext{
25Outras Palavras, composta e interpretada por Caetano Veloso. Disponivel em: https://youtu.be/G8LDjgGcTo>. Acesso em: 15/01/2016.

${ }_{26}$ Pequena morte, entoada por Pitty e disponivel em: <https://youtu.be/U6gmASkEkws>. Acesso em 15/01/2016.

27 Deleuze e Guattari (2012a), as três linhas da vida. No capítulo 3 trabalhamos as linhas da vida, exemplificando ao nosso modo.
} 
realidade de um determinado contexto histórico" (p. 13). A cartografia a qual se realizou surge, então, de uma "imersão na memória de sensações vividas naquele período" (p.21). Os aportes de Rolnik ajudaram a constituir os passos de um cartógrafo, bem como abre a concepção da micropolítica:

A cartografia, nesse caso, acompanha e se faz ao mesmo tempo em que o desmanchamento de certos mundos - sua perda de sentido - e a formação de outros: mundos que se criam para expressar afetos contemporâneos, em relação aos quais os universos vigentes tornaram-se obsoletos (ROLNIK, 2011, p. 23).

Micropolítica: forças que agitam a realidade, dissolvendo suas formas e engendrando outras, num processo que envolve 0 desejo e a subjetividade (ROLNIK, 2006, p. 123).

A inspiração na proposta cartográfica de Rolnik (2011) desloca o pesquisador para um lugar de experimentação das vivências deste campo, sobretudo no tocante à escrita. A concepção de experimentação já é em si mesma uma experimentação, tendo em vista os deslocamentos que ela ocasiona em forma de compreensão daquilo que vivenciamos, da forma como saboreamos o mundo. As experimentações já vinham sendo realizadas nas festas, antes do emergir como uma proposta de compreensão dos (curto)circuitos. É, portanto, justamente essa proposta cartográfica que veio deslocar o pensamento em direção a um texto que busca mergulhar nas memórias dos eventos, dos encontros e das músicas, na tentativa de narrar o invisivel: aquilo que só pode ser descrito como sensações. No mínimo, algo que se aproxima dos calafrios.

O próprio pesquisador-cartógrafo talvez deva estar atento aos limites das muitas contribuições em um quadro de referência fixo ${ }^{28}$, um referencial que buscaria explicitar os passos para que se consiga um bom trabalho cartográfico ele mesmo vai construindo junto ao campo as ferramentas que o servirão como operadores conceituais, bem como as lentes que possibilitarão uma visão ampliada dos sentidos daquele contexto. As músicas, livros, poemas, filmes e

\footnotetext{
28 Vale salientar realização de leitura de dossiês e livros sobre cartografias, mas sempre no sentido de enxergar possibilidades da criação de cartografias. Esses quadros existem enquanto narrações de experimentações, não como métodos a serem seguidos em seus pormenores.
} 
tanto mais são mediadores ${ }^{29}$ para potencializar não somente a escrita, mas a vida. Lentes para o olhar, como Suely Rolnik apresentou na sua Cartografia Sentimental (2011), e que fez com que se tentasse encontrar formas autorais de enxergar o invisivel. Mas também, algo próximo daquilo que apresentaram Deleuze e Guattari em seus Mil Platôs (2012a), quando os autores propuseram que há dois tipos de vigilantes: os de visão curta e os de visão ampla. Perceba-se que os vigilantes de visão curta trabalham com "lunetas simples", que cortam as coisas e que "todo mundo será julgado e retificado segundo os seus contornos, indivíduos ou coletividades" (DELEUZE; GUATTARI, 2012a, p. 81); são estes vigilantes com suas lunetas que operam por (re)cortes nas coisas e, com isso, "restaura a ordem molar por um instante ameaçada" (DELEUZE; GUATTARI, 2012a, p. 81). O segundo tipo, os vigilantes de visão ampla utilizam telescópios, são os que acompanham "migrações" e "deslocamentos" na matéria. Eis a diferença: olhar os contornos ou buscar ver como estão acontecendo deslocamentos? Questões de escalas: um dedica-se ao "molar", "macropolítico", o outro, ao "molecular", ao "micropolítico". Misturar Suely Rolnik que é uma grande devoradora de Deleuze e Guattari com eles mesmos, possibilitou que se buscasse, por vezes, um telescópio, mas ao mesmo tempo abandoná-lo e fugir um pouco para longe e ver somente as sensações do vazio que estão prolongando os corpos, ao menos os meus. Enxergar com o corpo, retirando os vidros dos olhos. Sei que pus nos olhos vidros pra melhor te enxergar, como canta Nando Reis, em Luz dos olhos ${ }^{30}$, mas os olhos já estão em outros lugares.

Ainda sobre a opção desse traçado cartográfico que mira o micropolítico, sentindo como canta SimonaTalma, na canção Seu Charme ${ }^{31}$, que dá o tom da imprecisão cantando: por isso não sonhe tão alto, baby, nem vá planejar demais, deixe o destino em paz. Afinal, o impreciso é tão mais sedutor, o pensamento sendo levado a perceber a composição de novos mundos e a obsolescência de

\footnotetext{
29Latour (2012) narrou em seu texto a noção de mediador enquanto algo que abre a problematização daquilo que pode revelar a gama de conexões presentes na sua criação. Os mediadores operam enquanto este meio de se ligar a outros corpos, a partir de encontros que revelam o que se conhece sobre algo.

${ }^{30} \mathrm{Luz}$ dos olhos de Nando Reis. Disponivel em: <https://youtu.be/B8IAuwp_elo>. Acesso em: 15/01/2016.

${ }^{31}$ Seu Charme de SimonaTalma. Disponivel em:<https://youtu.be/xm4-XlcmFoo>. Acesso em: 15/01/2016.
} 
outros, os vazamentos. O chicote da realidade agitando o corpo do mundo em espaços onde circulam músicas, mas, sobretudo corpos.

Cartografar é construir o mundo juntos, afetar-se nesse processo micropolítico, compor músicas em suas notas novas, apresentando possibilidades. Há, nessa proposta, de construir o mundo juntos, o afetar-se algo experimentado. Sensações que passam no corpo de quem cartografa e com isso escreve. A vida sendo narrada em eventos, que se torna a vida e retorna como texto que reaviva memórias. Refazendo os eventos em forma de memória e (re)construindo o mundo para uma escrita cartográfica e afetiva. O campo ressoando no pesquisador-cartógrafo e fazendo deste encontro a energia para produzir. Pode até parecer algo fácil, ou até mesmo suave, mas não é. Sentir os desmantelamentos de mundos, e, ainda assim, quando eles estiverem emergindo outros-mundos dói como fome, como falta do que respirar ${ }^{32}$, tal qual na canção de Ludov e, ainda assim, perceber se esses territórios novos permitem passagens. E a gente vai comendo o mundo, comendo aos pedaços corpos que se aventuram nas festas. Corpos que são músicas, músicas que são copos, copos que são celebrações da vida. A música da cantora P!nk dá o tom dos encontros. A cantora convida-nos a vida e convoca que ergamos os copos: Raise your glass if you are wrong in all the right ways, que traduzindo livremente seria um convite a levantarmos os nossos copos, nós que estamos errados em todas as formas certas. A vida que circula no dance floor33, nas ruas e, por fim, na cidade.

Seguindo, ainda, os aportes de Suely Rolnik no que concerne a questão "ética do cartógrafo":

O cartógrafo nada tem a ver com os mundos que se criam (que conteúdos, que valores, que línguas) - questão moral -, ele tem, e muito, a ver com o quanto a vida que se expõe à sua escuta se permite passagem; com o quanto os mundos que essa vida cria têm como critério sua passagem (ROLNIK, 2011, p. 70).

\footnotetext{
${ }^{32 E ́ ~ s o ́ ~ s a u d a d e ~ c a n c ̧ a ̃ o ~ d a ~ b a n d a ~ L u d o v . ~ D i s p o n i v e l ~ e m:<h t t p s: / / y o u t u . b e / k S t J M M q o r 7 w>. ~ A c e s s o: ~}$ $18 / 11 / 2015$

33 Dance floor é o termo em inglês para pista de dança.
} 
Ética antropofágica, abertura para deglutição de novos corpos que potencializam vidas, que permite sempre a expansão e não uma estabilidade. Talvez a metaestabilididade que fala Simondon ${ }^{34}$, tendo sempre novidades, mas perdendo-as para o mundo que se abre. Essa forma de pesquisa e experimentação diz respeito à corporificação da pesquisa, aos movimentos presentes no campo e das forças nas quais nos envolvemos; a corporificação da necessidade de criar e agir naquele campo de experimentação, e, por conseguinte, de conhecimento, como pontua Pozanna (2013). Como então agir após o ato antropofágico do campo e como não compor um texto carregado daquele linguajar, daquelas línguas vibrantes que expandem para que conheçamos mais do que ali mesmo circula? Traçar sempre linhas de fuga ${ }^{35}$ do próprio território que foi traçado. Nesse sentido, a cartografia foitecida justamente como atenta Rolnik quando estamos analisando o desejo, tendo em vista que "a análise do desejo é, necessariamente, análise de suas linhas de fuga, linhas esquizo por onde desmancham territórios: esquizoanálise." (ROLNIK, 2011, p. 71), mas também composições de fugas. Fugir da academia, que equivale a criar dentro dela, mesmo que através de uma escrita que experimenta ser ébria, almejando sempre ser louca ${ }^{36}$.

Um dos conselhos de Suely Rolnik (2011) é que se tenha uma "regra de prudência", com o intuito saber até onde o cartógrafo pode ir e o quanto ele consegue lidar com um "finito ilimitado", mostrando assim uma preocupação em até onde conseguimos nos desterritorializar, tendo em conta as "desorientações" e "reorientações dos afetos". Regra clara: quanto aguentamos devorar outras matérias e com elas retornar à composição de territórios nossos. Mas é na escrita que o peso destas desterritorializações aparecem. A reterritorialização na academia é algo que é necessário, para se pensar acerca das festas e das

\footnotetext{
34Virno (2009) e Deleuze dissertaram sobre a noção de individuação a partir de Gilbert Simondon. Atrelada a essa noção encontra-se a questão da metaestabilidade, trabalhada enquanto um pouso entre a estabilidade e desestabilidade.

35 Noção explorada neste capítulo no item 1.3. Deixaremos somente uma pista: "linha de fuga como corredor" (DELEUZE E GUATTARI, 2011, p. 30)

${ }^{36}$ A figura da louca inspira-se nas bichas loucas de Guy Hocquenghem (1980), que ao estarem presentes no grupo de homossexuais, dele se distancia, tendo em vista que as notas dissonantes entre cada uma das partes presentes no grupo faz com que as loucas sejam a abertura para novos modos de se vivenciar a homossexualidade através da festividade.
} 
musicalidades demandou que se buscasse um modo próprio para a pesquisa e a atuação acadêmica, revelando a nova postura de atuação acadêmica, e de vida.

Laura Pozanna dissertou acerca da corporificação do campo em nós, inscrevê-lo no nosso próprio corpo, porque "o aprendizado que nos forma, que nos traz ganhos, se faz sempre por inscrição corporal e não apenas por adesão teórica" (2013, p.324). Volta-se a um "fazer situado", que está sempre refletindo o contexto concreto da pesquisa. Para a cartografia é necessário que se criem modos de "fazer, perceber, sentir, mover e conhecer, que não se separa do mundo, dos objetos humanos e não-humanos em articulação - afetos em trânsito" (POZZANA, 2013, p. 332). Essa relação sensível da pesquisa pode mostrar as micropolíticas dos campos, o que de "concreto" passa por rupturas. A cartografia busca visualizar os deslocamentos, aquilo que "viabiliza o acesso ao plano de transformação da vida" (POZZANA, 2013, p. 329).

Eis a grande dureza, traçar um plano para que se possa atuar então na vida, transformando tudo aquilo que é pensado. Ao mesmo tempo em que tudo que é pensado está em vias de acontecer, como tornar essa possibilidade em uma máquina de guerra ${ }^{37}$ ? A desterritorialização de uma forma convencional da academia e reterritorialização nela própria com pensamentos-outros, atuando dentro deste espaço através de estratégias. Descobrir uma forma de atuação que consiga lidar com maneiras de viver que surgem nas ruas, considerando-as em suas danças. Ações micropolíticas, que buscam então neste espaço (re)fazer práticas, junto com outros com quem nos sintonizamos, mas para a consistência de própria prática de quem cartografa, na vida acadêmica e pessoal. Percebendo o que no mundo acontece, a preocupação que se segue é a de como produzir a partir dele. Por esse sentido tanto a cartografia como toda a teoria utilizada

\footnotetext{
37 A máquina de guerra, em Deleuze e Guattari (2012b), opera enquanto uma máquina que não divide segmentos, ela opera dentro deles. Mostrando o exemplo do jogo Go, onde as peças podem assumir qualquer direção, os autores mostram que, nesse sentido uma máquina de guerra é sempre uma estratégia. Ainda acerca da noção de máquina de guerra Deleuze (1992, p. 47) apresentou que ela atua "como um agenciamento linear que se constrói sobre as linhas de fuga". Continuando o autor frisou que ela não tem por objeto a guerra, mas sim "um espaço muito especial, o espaço liso, que ela compõe, ocupa e propaga" (idem).
} 
possibilita sempre agir como um pensador-menor ${ }^{38}$, que outros menores possibilitaram.

Não há uma separação na técnica da cartografia entre a "teoria e prática, espaços de reflexão e ação. Conhecer, agir e habitar um território não são mais experiências distantes umas das outras" (ALVAREZ; PASSOS, 2009, p. 149 apud POZZANA, 2013, p. 332). Pozzana ainda apontou uma valiosa contribuição encontrada em Latour (2007), que o nosso corpo trata-se de "uma trajetória dinâmica na qual nós aprendemos a nos tornar sensiveis àquilo de que o mundo é feito" (POZZANA, 2013, p.322). Há na tentativa de compor cartografias uma apropriação de acontecimentos micropolíticos, onde as conexões se dão entre corpos que se constroem. Tentar sair a campo e deliciar-se com a criação de possibilidades, de novidades, de linhas de fuga é tarefa cartográfica.

Um sujeito inarticulado é alguém que sempre sente, age e diz a mesma coisa. Um pesquisador inarticulado é aquele que vai a campo para confirmar o que já sabia, para coletar o que procurava, para aplicar uma teoria. Um sujeito articulado é alguém que aprende a ser afetado pelas outras pessoas e coisas. O pesquisador articulado vai a campo e move-se com ele para aprender, há um cultivo mútuo entre ele e aquilo que se faz presente no campo. (POZZANA, 2013, p. 333)

Um cartógrafo ousa tocar e ser tocado. Aprender mais com o campo. Esperar menos da teoria. Até aqui foi feito uso de muita teoria para falar de cartografia, o exercício é mais difícil que o pressuposto. Mas, de todo modo o campo atravessa a pesquisa, ressoa suas forças, aquilo o que é próprio do cartógrafo é levado na onda de forças desse atravessamento, percebe-se uma certa incidência de afetos a partir do campo. Nessa proposta cartográfica é buscado que se dê as mãos ao que pesquisamos sentir liberdade junto ao que estamos nos propondo: ao conhecimento. Estar aberto às surpresas que o nosso campo nos oferece, e com isso, mostrar os pequenos abalos que estão nos sendo apresentados. Para tanto, o cartógrafo necessita de uma abertura no seu

${ }^{38}$ Deleuze e Guattari na obra Kafka Para uma literatura menor (2003), deixam claras algumas questões acerca daquilo que os autores compreendem acerca do menor, marcando nesta noção que o menor não é definido pelo número menor, mas sim mostrando que a minoria se manifesta pela distância em relação ao que se configura como uma "característica axiomática dominante". 
corpo e deixa de lado as caixas de ferramentas que nos condicionam para uma compreensão rápida dos fatos.

A pesquisa foi sendo delineada na interação entre o mundo que o pesquisador não conhecia e passa a conhecer; a partir disso, ele pôde começar a desenhar o traçado das transformações. Reforço esse pensamento, dando ênfase ao meu mergulho em uma escrita musicalizada, bem como nas pesquisas teóricas que o campo desde então vem provocando a se fazer. Descobrir uma linguagem que, na escrita, esteja contida com os termos daquela realidade, daquelas pessoas, músicas, daquele fragmento do mundo.

Damo-nos conta de que, ao pensarmos na formação do cartógrafo precisamos pensar na produção de mundo, assim como nos dispositivos de pesquisa - práticas complexas de onde emerge pesquisador e pesquisado, problema e campo, sujeito e objeto. (POZZANA, 2013, p.336)

É neste campo empírico que aprendo a trabalhar com noções, assim como se faz na composição de músicas. Descubro que os conceitos são como as notas musicais, elas são as formas que utilizamos para musicar nossos pensamentos diante massa de dados de uma pesquisa em campo; eis que os dados são as letras dessas composições. Na "montação" 39 do texto estamos mostrando como compomos esse corpo-pensamento, trazendo conosco os autores, as festas. Nossos encontros potencializaram a escrita e a construção de uma pesquisa que levasse em consideração cada uma dessas questões.

\section{Pensar a música, pensar os encontros}

Eu não quero fazer o que eu já sei. Eu quero exatamente fazer o que eu não sei fazer. (Chico Buarque - Chico - artista brasileiro ${ }^{40}$ )

\footnotetext{
390 termo montação que utilizamos é proveniente do próprio campo. Kathisuca Combalaska fala desse termo enquanto o momento de preparação para subir ao Palco, assim como Dj BEE o faz, no público encontraram-se relatos de uso do mesmo termo para denominar o ato da preparação para ir à um evento. Utilizamos esse termo então como forma de demarcar que assumimos uma montação enquanto maneira de escrever e adentrar os campos da produção de conhecimento.

${ }^{40} \mathrm{Chico}$ Buarque, cantor, compositor e dramaturgo, intercalou falas e fases da sua vida e obra em um longa metragem, centrado no seu percurso nas artes e em momentos fora do palco. Deixamos disponível o trailer
} 
O nosso foco está no "disparo": a partir do momento em que se entra numa festa algo aconteceu, a partir do momento que conhecemos um corpo, algo está prestes a acontecer. Deleuze e Guattari esboçam, a esse respeito, aquilo que está acontecendo numa novela e em um conto. Citando o escritor norteamericano Fitzgerald, os autores mostram uma preocupação da percepção dos acontecimentos, com a cartografia pretendemos perceber "algo como já presente, tendo acabado de acontecer, mesmo se ainda não se realizou. Ou então sabe-se que o que está sendo realizado já o é pela última vez, terminou" (DELEUZE; GUATTARI, 2012a, p. 72). Ora, nas festas algo acaba de acontecer, entramos na festa, ouvimos uma música, dançamos. Mas algo está sempre prestes a acontecer, uma sequência. Mesmo assim, um mesmo algo jamais acontecerá novamente. Chance única de percepção da possibilidade de experimentar o mundo naquela duração. A festa habitada é composta por músicas, corpos e encontros, tornando-se um espaço que se abre para a possibilidade de acontecimentos que podem afetar os corpos.

Voltamos com Suely Rolnik (2011): na sua obra "Cartografia Sentimental" a autora expõe sua concepção de olhar vibrátil, no qual estaria contida a possibilidade de existir sensações que só são experimentadas pela imperceptibilidade dos acontecimentos. Sentir no corpo o sangue circulando nas veias, ele mesmo sendo um corpo que se agita e expande as energias da vida. A própria percepção pode se tornar única, passageira.

Belchior canta em Velha Roupa Colorida ${ }^{41}$ : \& Assum-preto me responde: O passado nunca mais? \& É esta pergunta que habita nosso texto. Unimos Belchior em seu questionamento com a canção Eclipse Oculto42 de Caetano Veloso: queremos sempre algo em relação ao outro, a um "você" que está no outro, mas que está na nossa relação. Abandona-se a relação, \& mas não deixo de querer

do filme Chico - artista brasileiro onde consta o trecho citado: <https://youtu.be/tmXoSU_4hU4>. Acesso em: 15/01/2016.

${ }^{41}$ Velha Roupa Colorida, Belchior. Disponivel em: <https://youtu.be/RA2PmL7hb30>. Acesso em: 15/01/2016.

${ }^{42}$ Eclipse Oculto, na interpretação do Barão Vermelho. Disponivel em: <https://youtu.be/YsBo5m9_zTM>.

Acesso em: 15/01/2016. Deixamos aqui a nossa predileção pela versão gravada pela banda Barão Vermelho. A voz de Cazuza convida a rebeldia no amor. 
conquistar uma coisa qualquer em você. O que será? \&. Aquilo que não é perceptivel é sempre desejado, tal qual Deleuze e Guattari frisaram. Cazuza poetiza que queremos algo da ordem de um mundo que não é passível de ser visto a olho nu, quando muito pelo olho do invisivel: \& meu mundo que você não vê meu sonho que você não crê $\delta$, cantado em Eu queria ter uma bomba ${ }^{43}$. Nossas bombas, que acionamos sempre quando em contato com outros corpos. Implosões, desejos, arrombamentos. Fogos de artificio, máquinas de guerra.

A vida está sempre em vias de acontecer, e, ao mesmo tempo está acontecendo. O próximo passo já foi dado no ato em que se pensa no porvir deste passo, sendo arrastado pela potência do que está por vir ${ }^{44}$. A micropolítica no ato da dança está justamente na vida que a dança pode possibilitar ao corpo. Sendo outro, mas sendo o mesmo e, ao mesmo tempo, não sendo o que é no agora, que já passa a ser para além do presente, do passado e do por vir. Os triplices mistérios do stop como cantam os Novos Baianos em Mistério do planeta ${ }^{45}$. É o prolongamento do momento que se desdobra nas conexões que este momento possibilita, enquanto um encontro que revela as conexões ando $e$ penso sempre com mais de um, novamente parafraseando a canção dos Novos Baianos.

Duas composições da cantora Pitty serão remixadas, em nossa tentativa de narrar nossos encontros possibilitam algumas reflexões. Estaremos então narrando, a seguir, um encontro: no nosso caso trata-se de um encontro musical que funciona enquanto um operador conceitual, cognitivo e afetivo; no caso do parágrafo que segue, todas as partes escritas em itálico como estamos realizando no decorrer do texto. Esses trechos dizem respeito a trechos de duas composições da cantora Pitty, nomeadas Anacrônico e Memórias, que foram, por nós, antropofagizadas e remixadas tal qual um DJ em sua atuação musical. O

\footnotetext{
${ }^{43}$ Cazuza - Eu queria ter uma bomba. Disponivel em:<https://youtu.be/w7QUSpggAro>. Acesso em: 15/01/2016.

44 O por vir, ou devir, está sempre na possibilidade de acontecer, a partir do momento que se descola do momento atual espelhado num passado.

45Mistério do planeta dos Novos baianos. Disponivel em: <https://youtu.be/f8SfDZ65A0o>. Acessa em: 15/01/2016.
} 
encontro com elas facilitou-se a compreensão e exposição de como este encontro funciona, exemplificando-o.

Do encontro entre dois corpos surgem memórias, que não só memórias, elas funcionam como fantasmas que me sopram aos ouvidos coisas que eu nem quero saber. É ao falar em afeto e agitações de campos de forças, presentes em subjetividades, que nos deparamos então com questões que zumbem aos nossos ouvidos. Que fique claro que somos as mesmas pessoas, mas o que se faz necessário perceber é que a partir de um encontro como o seu dia-a-dia mudou. Em muitos sentidos, a partir de um determinado encontro, mudamos os horários, hábitos, lugares e nisso fazer com que sejam percebidas coisas ao seu redor que outrora passariam imperceptíveis, até mesmo pessoas ao seu lado. São outros rostos, outras vozes interagindo e modificando você, e ai surgem novos valores, vindos de outras vontades. Ora, nesse encontro que surgem esses rostos, agindo em prol de modificações e que outras vontades surjam, fazem com que alguns [valores estejam] ${ }^{46}$ caindo por terra, pra outros poderem crescer. Percebamos: ainda há de se considerar que surgem então outras ambições mais fortes, somadas com as anteriores. Mudança de prioridades, mudança de direção, talvez uma deriva. Tudo isso em virtude de um encontro. Para além do fato dessa compreensão que essas músicas nos mostram que os encontros podem então ocorrer entre dois corpos. Meramente corpos humanos? Elas nos impulsionam a levar em consideração que encontros podem acontecer também entre produções musicais, corpos humanos e corpos de outras matérias, mas que também não se restrinjam àquilo que é de ordem material.

Almejamos, então, perceber o fluxo do desejo a partir do campo das produções artísticas, circunscritas em uma zona de fronteira - esta entendida como um local destinado àqueles que fogem e escapam às totalidades - e fazendo um levantamento da criação desse mundo-fronteira como linhas de fuga. Encontramos em Deleuze e Parnet (1998) vários trechos acerca das linhas de fuga, deixando algumas pistas que afirmam que as linhas de fuga são

\footnotetext{
${ }^{46}$ Utilizamos os colchetes para que pudéssemos então inserir partes nas letras da cantora, remixando com nossas propostas.
} 
criadores de devires ${ }^{47}$, e que "as linhas de fuga não têm território." (DELEUZE; PARNET, 1998, p.63). Encontramos também a ideia acerca do espaço de criação realiza-se nas linhas de fuga: "é sempre sobre uma linha de fuga que se cria, não, é claro, porque se imagina ou se sonha, mas, ao contrário, porque se traça algo real, e compõe-se um plano de consistência. Fugir, mas fugindo, procurar uma arma" (DELEUZE; PARNET, 1998, p.63). A arma das linhas de fuga são as explosões que elas realizam nas séries segmentares duras ${ }^{48}$. Ouçamos mais o som da fuga, as batidas do coração e o impacto da "quicada no chão" 49.

É por estar dentro de uma área perpassada por diferenças presentes em estilos musicais, nos participantes e em toda a ambiência da festa, que levantamos a seguinte questão: A própria festa como expansão do cotidiano não agiria em prol de uma abertura a levezas da vida?

Há nesse campo propostas que se vivenciem vidas clandestinas. Ou, dito de outra forma, que se viva em clandestinidade. Por que não aceitar o período noturno dos fins de semana como esse espaço para toda uma sorte de práticas clandestinas? HakimBey (2004) discute que as Zonas Autônomas Temporárias ou simplesmente T.A.Z. - tem consigo propósitos festivos, bem como dá-se em razão de uma "operação de guerrilha que libera uma área (de terra, de tempo, de imaginação) e se dissolve para re-fazer em outro lugar e outro momento, antes que o Estado possa esmagá-lo" (BEY, 2001, p. 17). É por não cessar de se refazer que as T.A.Z ${ }^{50}$ estão sempre se reformulando. Aqui não são compreendidas como espaços destinados à segregação ou segmentação, e distantes de todo o resto que se afirma como "centro" - se insurgem como espaços de expressividades sociais ébrias, deslocadas, festivas. Nossa pesquisa trata de compreender como que essas T.A.Z - constituídas de minorias (no sentido

\footnotetext{
47 Deleuze e Guattari (2003) descreveram o devir enquanto uma desterritorialização total. Com essa noção os autores discorreram que no devir algo se passa enquanto um corpo desconhece a trajetória dele.

${ }^{48}$ Cf. Deleuze e Guattari (2012a, p. 76).

49 Quicar é um termo utilizado para mostrar as pausas da bunda no ar. O corpo todo se movendo de um lado para o outro. O percurso do corpo tremendo, remexendo e podendo chegar ao chão. Uma das músicas em que falam do ato de quicar é a de Mc Delano que está disponível no seguinte link:<https://youtu.be/fkQXies7DSQ>. Acesso em: 15/01/2016.

50 Utilizamos a abreviação TAZ criada por HakimBey em inglês, no original servindo de contração para as seguintes palavras: Temporary Autonomous Zone. Se utilizássemos a abreviação da palavra em português ficaria: ZAT. Portanto, preferimos preservar o termo abreviado pelo autor.
} 
deleuziano), os marginais e marginalizados, ou qualquer nomenclatura que seja utilizada para denominar aqueles que são vistos como os 'desvios de rota' fazem uso de certos percursos para reinscrever esses territórios no mundo que os enxotou para as zonas de pouca inteligibilidade, entendidas na sociedade como zonas periféricas.

Nossa empreitada se aproximou de propostas teóricas, aqui mencionadas, no sentido em que buscamos ver a formação e transição de territórios, os processos de subjetivação que agem para efetuar deslocamentos no mundo e em seus territórios ${ }^{51}$, tornando-os espaços mais abrangentes, resistindo e agindo para tal, bem como estando longe de ser algo estático. Movimentos ocasionados por bandos abertos por aqueles corpos que dividem afinidades, "redes de pessoas com interesses específicos" como disse HakimBey (2004, p. 24). Afinidade de esfregar os corpos em funks, batidões, como convida o Bonde do Role em Divine Gosa(sic): Esfrega daqui e roça de lá, arranha a aranha pra chapa esquentar. Deda daqui e lambe de lá, arranha a aranha pra chapa esquentar. Convites, afinidades, interesses. Tudo presente na atmosfera da festa, realizando chamadas para percorrê-lo de corpos que estão a fim da troca de toques.

A essência da festa: cara a cara, um grupo de seres humanos coloca seus esforços em sinergia para realizar desejos mútuos, seja por boa comida e alegria. Por dança, conversa, pelas artes da vida. Talvez até mesmo por prazer erótico ou para criar uma obra de arte comunal, ou para alcançar arroubamento do êxtase. (BEY, 2004, p. 24-25).

A zona de intensidade, que se constitui em platôs sensoriais, convida: Gozemos da festa, em festa e para a festa. Elaboremos artes para a vida, vida com outros corpos; corpos com mais vida, cintilantes e lantejoulados. Há nisso a proposta de rompimento com a ideia somente de que os humanos compõem a T.A.Z.. Convidamos para que seja compreendido que os corpos de matérias não

51 Podemos citar, de maneira breve, através de Takeuti (2012), os territórios juvenis sendo pensados pela autora como "uma multiplicidade de espaços onde são: postas em prática ações e estratégias para a produção de bens materiais e imateriais (de natureza artística, cultural, científica, tecnológica ou econômica); produzidos discursos, informações e conhecimentos, bem como experimentações grupais ou coletivas diversificadas principalmente mobilizando repertórios do universo da arte e cultura, com fins lúdicos, político ou econômico" (TAKEUTI, 2012, p. 9). 
humanas também são partes integrantes e fundamentais em uma festa. O que seria da festa sem as comidas, as bebidas, as músicas? Restariam somente os corpos humanos para serem antropofagizados. Quando a música não estiver convidativa para os corpos dançarem e a pista não estiver "fervendo", o evento fracassa, os corpos se dispersam. Fogem, talvez em busca de algo melhor, que seja sua cama ou a de alguém.

A vida nas festividades, atravessadas por músicas, compondo finais de semana, em processos que envolvem diretamente territorialização, desterritorialização e reterritorialização da cotidianidade, conceitos trazidos a partir de Deleuze e Guattari (2003). É essa a aposta: de que todos os partícipes em festas, com arte, vão transformando suas vidas a partir de ares amenos. A noção de territorialização para mostrar as sobrecodificações compostas nos agenciamentos coletivos, onde a vida é apreendida, regida a partir do mundo que se expressa através de territórios em que a vida é ordenada; desterritorialização em se tratando do movimento da fuga, o momento em que se é possível em pensamento se tornar nômade, desconhecer seu entorno, é nesse momento que o devir se instaura preenchendo as ideias com outras intensidades; para que então a reterritorialização, o último movimento, onde o pensamento alcança concretude, é posto em ação, onde ele está expresso - e passa a agenciar outras intensidades, saindo dos territórios imaginados e sendo derramado sobre a terra.

Se esses corpos estão sendo atravessados por forças que thes desmantelam, essas forças emanam do fluxo do desejo presente no campo de subjetivação que atravessa as relações dos corpos. Compreendendo o desejo não como falta, mas sim como uma força que intenta possibilitar com que os corpos entrem em campo e possam transformar os próprios desejos em forças que transformam o mundo no qual vivem. Aquilo que potencializa a vida seria justamente a força presente do desejo, enquanto "potência de vida" que faz com que se resista aos espaços instituidos e que lhes subvertam a ordem, crie-se espaços. Desordenar o entorno da realidade, a partir do desejo, para que assim a 
vida - não a vida individual, mas sim coletiva, a vida na multidão52 - possa ser exercida.

Falamos de desejo e nos remetemos a Deleuze e Guattari, em suas questões relativas aos agenciamentos e as maquinações. Os autores nos mostraram que ele está sempre atrelado ao devir, entendendo que "desejar é passar por devires" 53. É na maquinação do desejo que ele pode se tornar um agenciamento. Atentamos que um desejo está na possibilidade de se transformar em um agenciamento ou não. Quando ele ainda se encontra na maquinação ele está sendo concebido enquanto um devir que é alcançado através de uma linha de fuga, que já não mais tem relação com ausentar-se geograficamente de uma localidade à outra, mas sim como dentro do próprio local ao qual se está vinculado, onde se consegue "cavar" nele um outro espaço onde o desejo presente na linha de fuga possa encontrar uma forma de ser alcançado.

Ao utilizarmos esse conceito de desejo em nossa pesquisa, nosso intuito é de compreender o fluxo nesse meio musical. Um cantor produz uma dobra54, dentro de um ritmo e abre outras possibilidades. A voz esganiçada que alcança no funk um espaço para entoar suas canções é um exemplo disso. A ironia na letra de um tenor lírico que com sua mente em forma de "máquina de putaria" processa composições de outras pessoas e faz delas versões para "maiores de dezoito anos". Aquele jovem que se desloca de casa até uma festa e nela encontra o espaço onde possa dar seu close e assim coreografar com seus amigos o melhor videoclipe da última semana de todos os tempos. Há nessa ambiência diversos encontros acontecendo e que são alcançados somente em

\footnotetext{
52Virno (2009) apresentou que na multidão há um principio novo acerca daquilo que seria um Uno, como essa multidão sendo a derivação dessa ideia de Uno. O autor ainda nos atentou que na multidão o que está presente é uma "individuação, ou na derivação de cada um(a) da multidão a partir de algo de unitário/universal" (VIRNO, 2009, p.28). A ideia de individuação é proveniente de Gilbert Simondon, e nos apropriamos dela partir de Virno. Este traz ainda que "o conceito ético-político de multidão funda-se tanto sobre o principio de individuação como sobre sua incompletude constitutiva" (VIRNO, 2009, p. 35) desse ser que está sempre em um processo. Negri (2009, p. 15) diz que a "multidão é um conjunto de singularidades" como acentua que ela "é sempre produtiva e está sempre em movimento".

53 Concepção utilizada a partir de O Vocabulário de Deleuze escrito por François Zourabichvili (2004), no que concerne ao vocábulo devir.

54Takeuti (2012), devoradora de Deleuze e Guattari, faz uso desta noção para mostrar como a partir de experimentações juvenis são criadas possibilidades de vida, dobrando e desdobrando suas vidas e existências em ambientes que estabelecem contato.
} 
um determinado espaço de tempo, que demanda um local e um grupo específico.

No palco, mas não só nele, no espaço reservado ao público também, uma gama de encontros vão sendo desenvolvidos de várias formas. Os performers entram em cena utilizando de recursos materiais, quer sejam as roupas, as maquiagens utilizadas para modificação dos rostos, o glitter, o leque e por fim o microfone para potencializar a voz. No público, quem assiste, também mobilizou esses mesmos corpos que em assim sendo estão compondo uma imagem, uma composição de corporalidades. Nessa perspectiva, há uma conexão entre corpos humanos e corpos não humanos ${ }^{55}$; apreendemos que essa utilização de matérias serve para endossar características-outras, presentes naqueles corpos humanos e nas coisas. A questão que emerge então agora é a de perceber como esses corpos não humanos são deslocados da lógica onde eles são compreendidos como potencializadores de características humanas e passam a agir como potencializadores de características-outras, perto de algo como um corpo híbrido. Descontinuar a ideia de que somente os corpos humanos estão sendo desterritorializados nesse percurso; mas queremos entender que também os corpos das coisas são desterritorializados para quando movimentarem-se em direção da reterritorialização estes passem a compor então a máscara que performa a junção dos corpos do humano e do não humano em uma composição que carrega esse atravessamento do encontro entre ambos. Há, no campo das artes, a questão que permeia as indumentárias, pensando que estas poderão fazer com que os corpos possam resignificar suas trajetórias, e, o uso deste espaço, que é o corpo como local de criação de personagens que estariam então apresentando desta forma ao público uma máscara artística, que está presente naquele corpo atravessado.

Isso nos remete à indagação feita por Deleuze e Guattari (2011) quando pensaram em um Corpo sem Orgão56: "Que tipo é este, como ele é fabricado, por que procedimentos ele é fabricado e meios que pronunciam o que vai

55 Cf. Bruno Latour em sua obra Reagregando o Social (2012).

${ }^{56}$ Que daqui em diante utilizaremos a abreviação CsO para designar a noção de Corpo Sem Órgãos, abreviação que Deleuze e Guattari utilizaram. 
acontecer". Ora, o corpo é carregado de indumentárias; ele é marcado por traços, camadas e mais camadas de maquiagens, glitter, paetês, sombras cintilantes. Mas ainda nada passou. Chega-se à noite, o corpo é jogado nela. Algo está por acontecer desde que saiu de casa. Mas ainda não aconteceu, está em vias de acontecer. SAnd everything so unexpected the way you right and left it so you can keep on taking it $\mathbf{5 7}$. Os corpos que se movem, os corpos das roupas, das maquiagens, dos humanos, das músicas.

CsO só pode ser habitado por intensidades, fazendo-as passar ou não. Então qual é a intensidade que a música faz passar para estes CsO? sCan't stop, won't stop moving. It's like I got this music in my mind say in' it's gonna be al right \$58 e vida que segue se esgueirando por entre as fendas dos corpos, pelas bordas das caixas de som, por cabeças arreganhadas pela translucidez dos doces 59 .

Com as provocações das frases eu não moro mais em mimº e você quer ir embora de você como se você não the fosse todos os destinos possiveis ${ }^{61}$, unimos Adriana Calcanhotto e a banda Plutão Já Foi Planeta,com a intenção de alargar as duas propostas: a de não morar mais em si como um lugar, mas também não descolar das possibilidades dos desterritorializações na geografia deste corpoimagem que devém turista de si. Esta viagem perdida nos circuitos de musicalidades pode fazer com que algo seja lançado e ainda assim descolado do desejo de resolução imediata de um problema, mas, mesmo assim pode ser ainda uma chance para aquele corpo que não encontra uma saída para um destino possivel62.

O corpo como lugar para saídas dos destinos possíveis, das fugas. "O corpo é tão somente um conjunto de válvulas, represas, comportas..." dizem

57 Trecho da canção Hipsdon't lie de Shakira. Tradução livre: E tudo tão inesperado / A maneira que você vai da direita para a esquerda / Então você pode continuar fazendo isso. Canção disponível em: <https://youtu.be/DUT5rEU6pqM>. Acesso em: 15/01/2016.

58 Trecho da canção Shake it off de Taylor Swift. Livre tradução: Não posso parar, e nem vou parar de me mexer / É como se tivesse uma música na minha mente / Dizendo que tudo vai ficar bem. Disponivel em: $<$ https://youtu.be/nfWlot6h_JM>. Acesso em: 15/01/2016.

59 Um segredinho que descobrimos nas noites: doce ou LSD são designações para drogas sintéticas.

${ }^{60}$ Metade, canção de Adriana Calcanhotto. Disponivel em: 〈https://youtu.be/Tq2gOFywWEc〉. Acesso em: 15/01/2016.

${ }^{61}$ Viagem Perdida é uma canção da banda Plutão Já Foi Planeta. Disponivel em: https://youtu.be/l7KktLEdFrc. Acesso: 15/01/2016.

62 Igual nota anterior. 
Deleuze e Guattari (2012a. p. 16). Se esta é a imagem do corpo, o CsO é o arrombamento destas válvulas, tornar o corpo em escape. A música pode então convocar para que o $\mathrm{CsO}$ seja isto, um vazamento do estado de represa, para então tornar-se torrente que arrasta a vida para fora de um "nome próprio", uma sangria de açude ${ }^{63}$ em uma festa. Precisando vazar, para não deteriorarmos todo o território-corpo.

O prazer atingido pelo CsO em música se dá pelo aumento de um desejo, "intensidades de prazer". No campo das festas as intensidades são prolongadas pelas sensações pelas quais o corpo é atingido em contato com as músicas. Os sons ecoam no ambiente como balas disparadas e devoradas pelo céu da boca, - corpo se distribui pelo espaço do dance floor. Qual imagem então está emergindo a partir disto? Corpos suados e cansados de tantas músicas, roucos e abertos às ressacas?

Devir-partitura que flutua entre as linhas da vida. A questão é justamente essa, prolongar a linha da vida nos momentos em que o corpo é jogado na noite, e, a partir da jogação, retornar aos espaços mais segmentados para neles também habitar.

\section{Referências}

BEY, Hakim. TAZ - Zona Autônoma Temporária. São Paulo: Conrad, 2004.

DELEUZE, Gilles. Conversações. São Paulo: Ed. 34, 1992.

DELEUZE, Gilles; GUATTARI, Félix. Kafka: para uma literatura menor. Rio de Janeiro: Assírio \& Alvim, 2003.

Mil Platôs: capitalismo e esquizofrenia. Vol. 1. Rio de Janeiro: Ed. 34, 2011.

Mil Platôs: capitalismo e esquizofrenia. Vol. 3. Rio de Janeiro: Ed. 34, 2012a.

Mil Platôs: capitalismo e esquizofrenia. Vol. 5. Rio de Janeiro: Ed. 34, 2012b.

63 Os açudes presentes nos interiores do Nordeste quando chegam a capacidade máxima e transbordam por cima das represas são memórias nítidas quando os autores falam de válvulas, comportas e represas. A utilização do termo dá em razão da nomeação desse ato para designar o momento em que os açudes enchem, e para não romper a barragem, abrem-se as comportas para queas águas, com sua força avassaladora, não estourem as paredes. 
DELEUZE, Gilles; PARNET, Claire. Diálogos. São Paulo: Escuta, 1998.

LATOUR, Bruno. Reagregando o Social. Salvador: Edufba; Bauru, São Paulo: Edusc, 2012.

NEGRI, Antonio. Para uma definição ontológica da Multidão. Revista: Lugar Comum. Vol. 19-20, p.15-26, 2009.

ROLNIK, Suely. Geopolítica da cafetinagem. Ide. São Paulo, v. 29, p. 123-129, 2006.

Cartografia Sentimental: Transformações contemporâneas do desejo.

3. ed. Porto Alegre: Sulinas, 2011.

POZZANA Laura. A Formação do Cartógrafo é o mundo: corporificação e afetabilidade. Fractal: Revista de Psicologia, v. 25, p. 323-338, 2013.

TAKEUTI, N. Dobras na juventude e nomadismo. Latitude, v. 6, p. 7-23, 2012.

VIRNO, Paolo. Multidão e princípio de individuação. Revista: Lugar Comum. Vol. 19. p. 27-40, 2009.

ZOURABICHVILI, François. O Vocabulário de Deleuze. Rio de Janeiro: Relume Dumará, 2004. 